Argonne Rational Laboratom

THE CONTINUOUS MONITORING OF BORIC ACID CONCENTRATION BY NEUTRON ABSORPTIOMETRY

by

Roland J. Armani 


\section{DISCLAIMER}

This report was prepared as an account of work sponsored by an agency of the United States Government. Neither the United States Government nor any agency Thereof, nor any of their employees, makes any warranty, express or implied, or assumes any legal liability or responsibility for the accuracy, completeness, or usefulness of any information, apparatus, product, or process disclosed, or represents that its use would not infringe privately owned rights. Reference herein to any specific commercial product, process, or service by trade name, trademark, manufacturer, or otherwise does not necessarily constitute or imply its endorsement, recommendation, or favoring by the United States Government or any agency thereof. The views and opinions of authors expressed herein do not necessarily state or reflect those of the United States Government or any agency thereof. 


\section{DISCLAIMER}

Portions of this document may be illegible in electronic image products. Images are produced from the best available original document. 
$\infty$

\section{LEGAL NOTICE}

This report was prepared as an account of Government sponsored work. Neither the United States, nor the Commission, nor any person acting on behalf of the Commission:

A. Makes any warranty or representation, expressed or implied, with respect to the accuracy, completeness, or usefulness of the information contained in this report, or that the use of any information, apparatus, method, or process disclosed in this report may not infringe privately owned rights; or

B. Assumes any liabilities with respect to the use of, or for damages resulting from the use of any information, apparatus, method, or process disclosed in this report.

As used in the above, "person acting on behalf of the Commission" includes any employee or contractor of the Commission, or employee of such contractor, to the extent that such employee or contractor of the Commission, or employee of such contractor prepares, disseminates, or provides access to, any information pursuant to his employment or contract with the Commission, or his employment with such contractor.

Price 50 cents. Available from the office of Technical Services, Department of Commerce, Washington 25 , D.C. 
ANL- 6439

Instruments

(TID-4500, 16th Ed., Amended)

AEC Research and Development Report

\section{ARGONNE NATIONAL LABORATORY 9700 South Cass Avenue \\ Argonne, Illinois}

THE CONTINUOUS MONITORING OF BORIC ACID CONCENTRATION

BY NEUTRON ABSORPTIOMETRY

by

Roland J. Armani

Reactor Engineering Division

October 1961

Operated by The University of Chicago under

Contract W-31-109-eng-38 
TABLE OF CONTENTS

Page

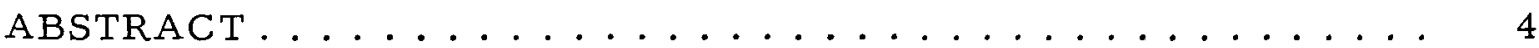

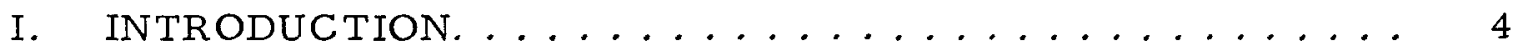

II. DEVELOPMENT AND DESIGN ............... 5

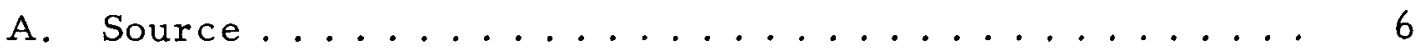

B. Detector......................... 8

C. Electronics...................... 8

III. STABILITY AND TEMPERATURE MEASUREMENTS . . . . 10

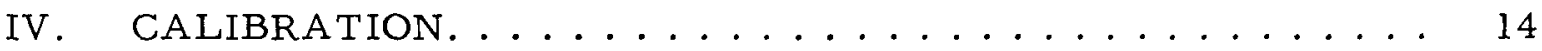

V. INSTALLATION AND INITIAL EXPERIENCE ........ 16

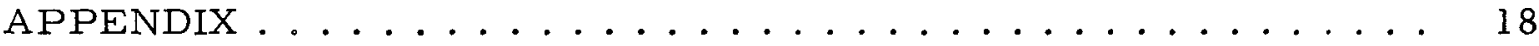

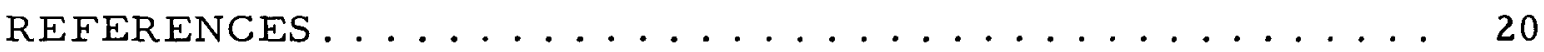

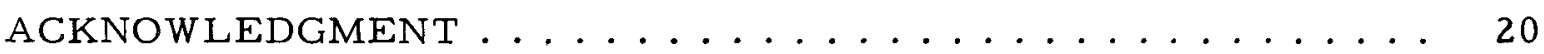




\section{LIST OF FIGURES}

No.

Title

Page

1. Boric Acid Concentration vs Change in Electrometer Output

Parametric with Source Position............. 5

2. Boric Acid Monitor Cell .................. 7

3. Standard Ionization Chamber Circuit Using a Vibrating Reed

Electrometer...................... 8

4. Current-Voltage Characteristics of the Neutron Ionization

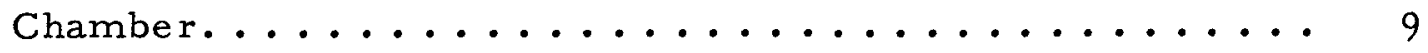

5. Standard Ionization Chamber Circuit with Feedback Added. . 10

6. Loop Setup Use for Testing and Calibrating the Boric Acid

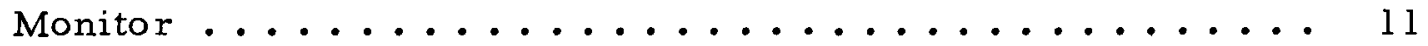

7. Instrument Response as a Function of Temperature ...... 12

8. Instrument Response as a Function of Temperature ...... 13

9. Instrument Response as a Function of Temperature ...... 13

10. Instrument Response as a Function of Temperature ...... 14

11. Monitor Calibration Curve................ 15

12. Modified Output Circuit of Vibrating Reed Electrometer . . 16

\section{LIST OF TABLES}

No.

Title

Page

I. Current as a Function of Source to Detector Distance . . . 6

II. Comparison of Monitor and Chemical Results ........ 16 


\title{
THE CONTINUOUS MONITORING OF BORIC ACID CONCENTRATION BY NEUTRON ABSORPTIOMETRY
}

by

Roland J. Armani

\begin{abstract}
A neutron absorption cell has been built to monitor continuously the boric acid concentration of reactor water flowing through a purification loop. The instrument has been calibrated over the range from 0 to $2.65 \mathrm{gm} /$ liter with a maximum absolute error of $0.05 \mathrm{gm} / \mathrm{liter}$.
\end{abstract}

\section{INTRODUCTION}

In the operation of the EBWR at higher power levels (20 to $100 \mathrm{Mwt}$ ), boric acid will be used to provide a reactivity margin for shutdown. (1) Several means are available for monitoring boric acid concentration in the moderator, including chemical titration, photometric determination, and a neutron absorption technique.

The neutron absorption technique is feasible for the determination of soluble poisons in water and a number of other solvents. This method was investigated for the monitoring of boric acid concentration in the EBWR water moderator, and an instrument was developed on the principle of neutron absorptiometry which meets the following conditions:

(1) The instrument operates over a concentration range from 0 to $2.65 \mathrm{gm}$ of boric acid per liter of water.

(2) The sensitivity of the instrument is $0.05 \mathrm{gm}$ of boric acid per liter of water.

(3) It is capable of monitoring the boric acid concentration in a flowing sampling stream of reactor water.

(4) The instrument operates comparatively independent of temperature.

(5) It is stable and results are reproducible.

(6) The operation of the instrument is simple. 


\section{DEVELOPMENT AND DESIGN}

Work previously done with the technique involved the use of $\mathrm{BF}_{3}$ counting chambers with a suitable neutron source.(2,3) The geometry was such that the source neutrons were moderated and passed through the liquid sample before reaching the detector. The samples were then counted, and the poison concentration was related to the counting rate. In the development of the completely continuous monitoring system, the counting chamber was replaced by a $\mathrm{BF}_{3}$ ionization chamber.

Preliminary measurements were made by placing a $\mathrm{BF}_{3}$ ionization chamber in the center of a tank of water and a source of neutrons on the outside edge of the tank. A small current was observed, and the addition of boric acid to the water caused enough reduction in the current to continue investigation on this method.

Geometries were investigated to optimize current in the $\mathrm{BF}_{3}$ chamber and sensitivity to the introduction of boric acid. A circular tank, $30.5 \mathrm{~cm}$ (12 in.) in diameter and $45.8 \mathrm{~cm}$ (18 in.) high, was fabricated so that the detector could be fixed in the center, and the source could be moved inside the tank closer to or away from the detector. The tank was filled with water, and known amounts of boric acid were added. The change in electrometer output as a function of source position was noted (Figure 1 and Table I).

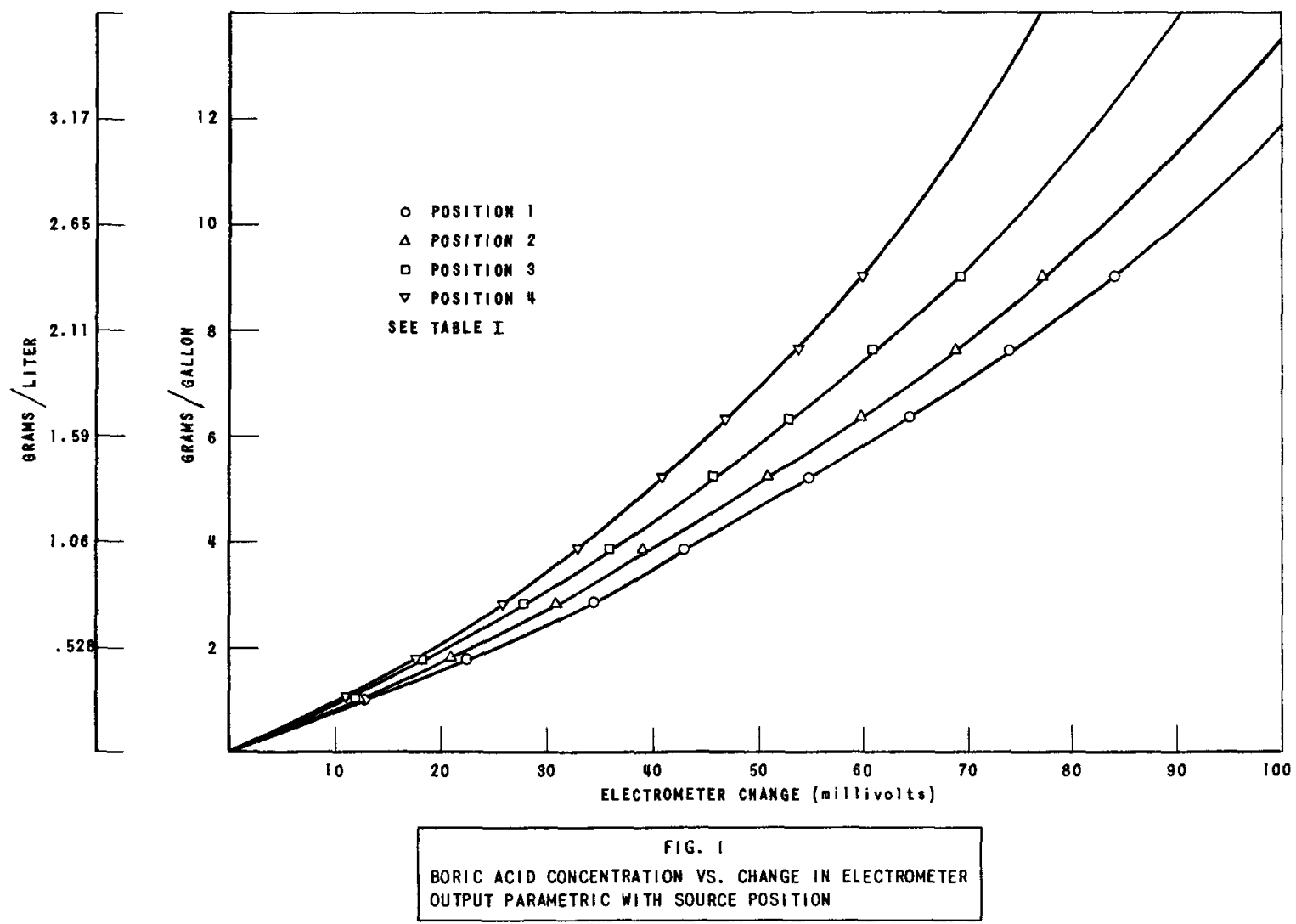


This information shows that for those distances where measurements were made, the fractional current change is independent of the distance from source to detector. The maximum current is obtained when the source and detector are as close together as possible.

Table I

CURRENT AS A FUNCTION OF SOURCE TO DETECTOR DISTANCE

\begin{tabular}{|c|c|c|c|}
\hline \multirow{2}{*}{ Position } & $\begin{array}{c}\text { Source to Detector Distance, } \\
\text { Center to Center }\end{array}$ & $\begin{array}{c}\mathrm{I}_{0}{ }^{*} \\
(\mathrm{amp})\end{array}$ \\
\cline { 2 - 3 } & $(\mathrm{cm})$ & (in.) & $0.4 \times 10^{-9}$ \\
\hline 1 & 5.08 & 2 & $0.37 \times 10^{-9}$ \\
2 & 7.62 & 3 & $0.33 \times 10^{-9}$ \\
3 & 10.16 & 4 & $0.28 \times 10^{-9}$ \\
\hline
\end{tabular}

Note: See Figure 1.

* Current with 0 concentration

A place was chosen in the moderator purification system of EBWR where a boric acid monitoring cell could be installed. The reactor water flows from the core, through a filter, into the monitor cell, and into an ion exchange system. From there the water is pumped back to the core. The maximum temperature and pressure existing in this line are $50^{\circ} \mathrm{C}$ and $42 \mathrm{~atm}$. In order to use reasonable wall thicknesses, it was necessary to reduce the diameter of the cell, but still have it large enough to thermalize the source neutrons and keep the thermal neutron leakage low. Current measurements were made with various cell diameters, and it was found that $20.32 \mathrm{~cm}$ ( 8 in.) would be satisfactory for moderation as well as a reasonable engineering design. The length of the cell was made long enough to utilize all of the sensitive volume of the $\mathrm{BF}_{3}$ ionization chamber. Figure 2 is a drawing of the finished monitor cell with entry tubes for the detector and source. A baffle was included to insure good flow with no stagnant water in the cell.

\section{A. Source}

It is desirable to use as large a source of neutrons as possible within limits of radiation safety and shielding requirements, in order to produce a large current and minimize statistical fluctuations. A long half-life would reduce the change in current with time and the need for constant calibration of the instrument. 


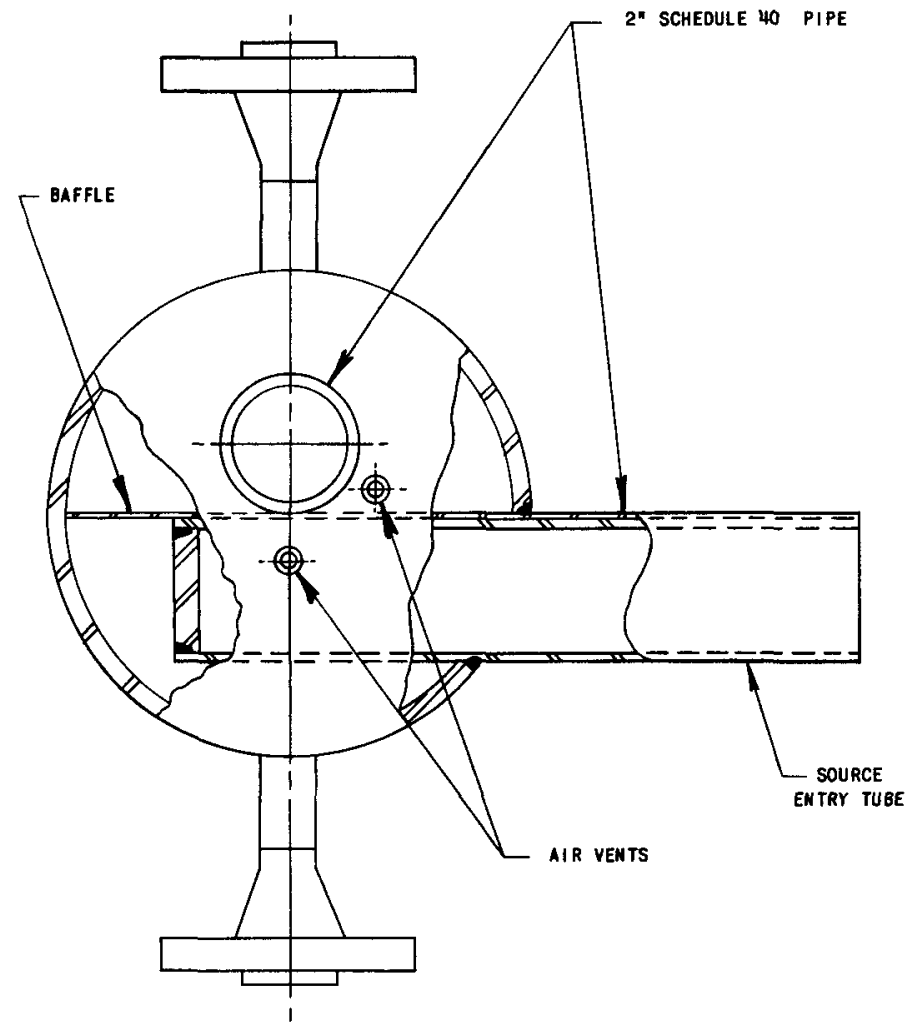

MATERIAL - TYPE 304 SS

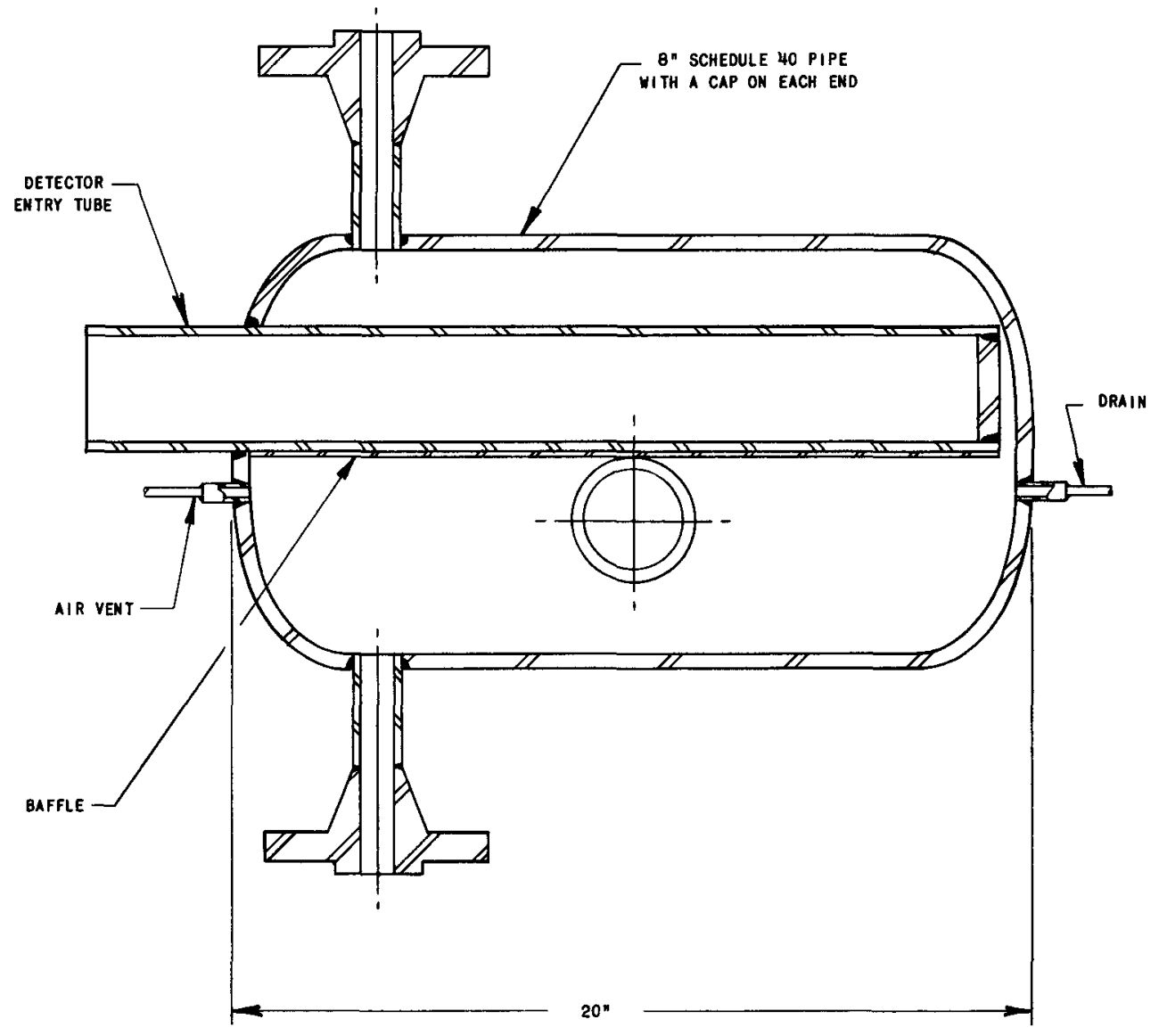

FIG. 2

BORIC ACID MONITOR CELL

$\checkmark$ 
An essentially gamma-free source would eliminate part of the health hazard and also reduce background at the neutron detector. A plutonium-beryllium neutron source was chosen, since it is gamma-free and has a half life of 24,600 years. Mound Laboratory fabricated the source of $110 \mathrm{gm}$ of plutonium intimately mixed with $54 \mathrm{gm}$ of beryllium. It gives a neutron output of $1.28 \times 10^{7}$ neutrons/sec. This source and geometry produce a current of $0.66 \times 10^{-9}$ amp with demineralized water in the cell. With this current, the statistical variation in the current is about $\pm 1 \%$.

\section{B. Detector}

The detector used is a $\mathrm{BF}_{\mathbf{3}}$ gas-filled ionization chamber purchased as a stock item from Neutronics Laboratory, Tinley Park, Illinois, This chamber can be operated in environments up to $315^{\circ} \mathrm{C}$. It is highly shockproof and fairly insensitive to gammas. Details on this detector may be found in the Appendix.

\section{Electronics}

The electronics used in the current measurements includes a Model 30 Vibrating Reed Electrometer (VRE), a-1/0/10 millivolt Brown Recorder, a 1200 -volt battery power supply, and $0 / 1$ volt transistorized feedback supply.

A standard ionization chamber circuit (Figure 3) was used to determine the current-voltage characteristics of the ionization chamber. Figure 4 indicates that 1200 volts is a suitable level for the high-voltage supply .

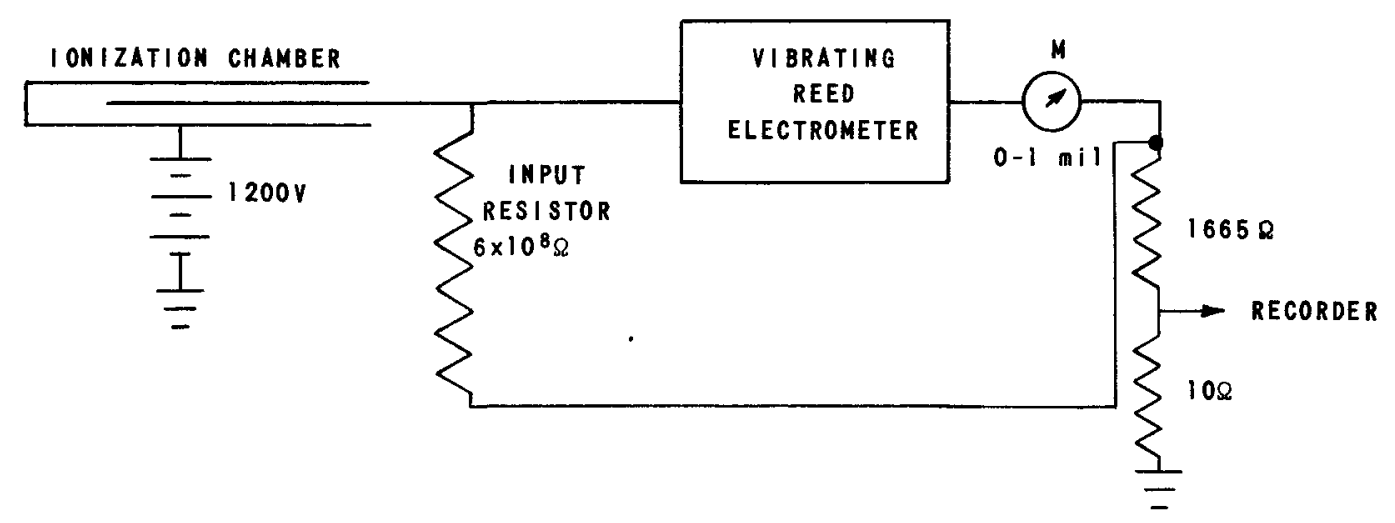

FIG. 3

STANDARD IONIZATION CHAMBER CIRCUIT USING A VIBRATING REED ELECTROMETER 


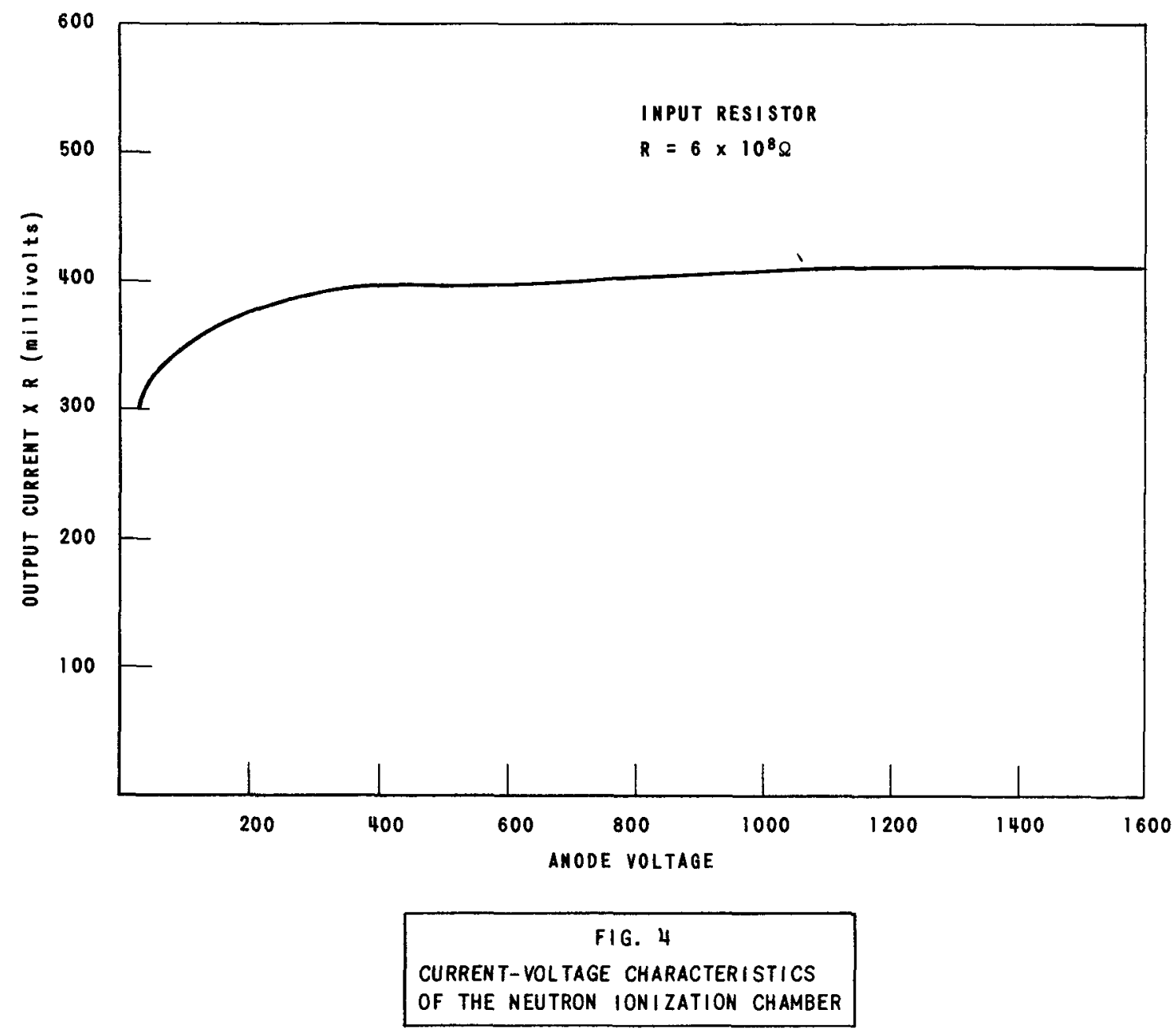

Measurements with and without boric acid in the cell indicated that the addition of $2.65 \mathrm{gm}$ of boric acid per liter of water decreased the current approximately $25 \%$ from the initial value with demineralized water. Modifications were made in the electronics so that demineralized water indicates zero on the VRE and a concentration of $2.65 \mathrm{gm}$ of boric acid per liter of water indicates full scale on the instrument.

In this circuit, the VRE is used as a high-impedance voltmeter which indicates the voltage drop across the input resistor (Figure 3). The input resistor was selected so that the voltage reading obtained with demineralized water was approximately 400 millivolts. A feedback circuit was introduced into the system which reduced or "bucked-out" the voltage on the electrometer to zero. A concentration of $2.65 \mathrm{gm}$ of boric acid per liter of water results in a meter reading of -100 millivolts. A meter reversal switch on the electrometer reverses the polarity, and the meter reads upscale rather than below zero. The instrument reads zero for demineralized water and 100 millivolts for a concentration of $2.65 \mathrm{gm}$ per liter. The range switch on the VRE is set on 100 millivolts full scale, so that a fullscale deflection is observed at maximum concentration. Figure 5 shows the circuit for the modified system. 


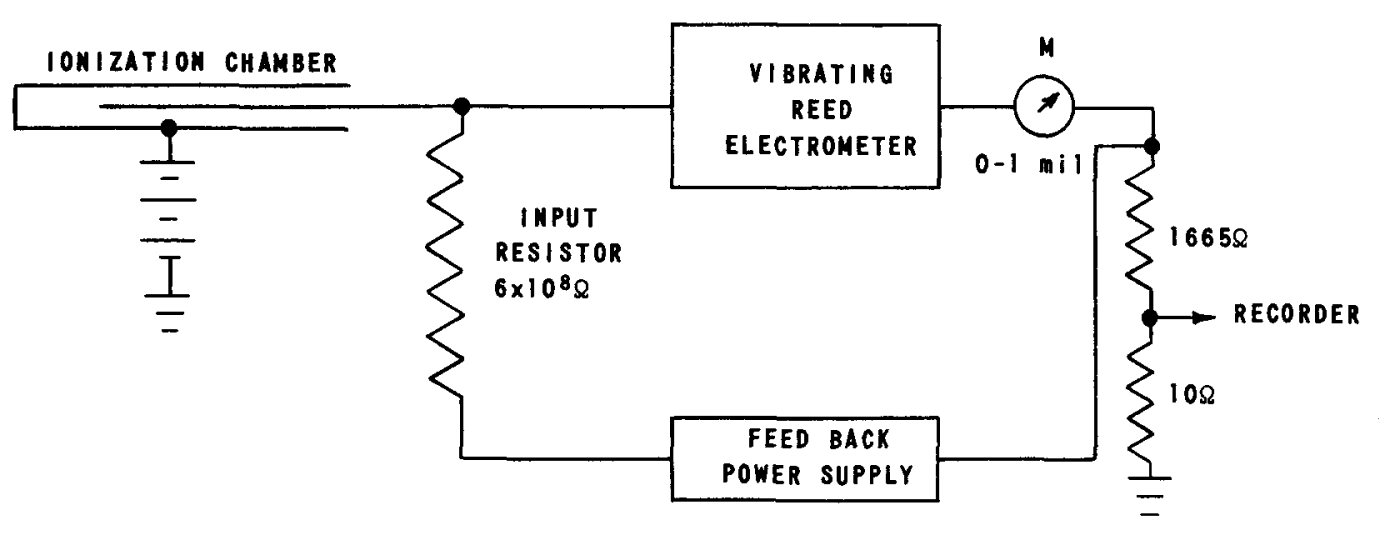

FIG. 5

STANDARD IONIZATION CHAMBER

CIRCUIT WITH FEED BACK ADDED

In bucking out the VRE signal, the $d-c$ portion is reduced to zero, but the a-c statistical variation or "noise" remains unchanged. When the VRE range switch is set from $1000 \mathrm{mv}$ to $100 \mathrm{mv}$ full scale, the noise is amplified by a factor of 10 . With this amplification, the noise level is seen as $\pm 4 \mathrm{mv}$. This variation cannot be eliminated unles much larger currents are produced. Since it is not feasible in this system, the recorder has been mechanically damped to allow the signal displayed on the chart to be more easily read. A 50-rpm motor was substituted for the normal pen balance motor $(180 \mathrm{rpm})$. This reduced the high-frequency response of the recorder and reduced the noise to $\pm 2 \mathrm{mv}$.

Because of the noise, it is difficult to zero the VRE with the panel meter. The recorder is used, and the signal trace gives an accurate zero adjustment. The $-1 / 0 / 10$ range is used since this moves the recorder zero one unit from the edge of the chart, so that the zero trace may clearly be seen.

The recorder was checked with a potentiometer and found to be linear. A check of the panel meter on the VRE showed it was not linear. For this reason all measurements were made by reading the recorder and ignoring the panel meter on the VRE.

\section{STABILITY AND TEMPERATURE MEASUREMENTS}

A loop was set up so that water or a solution of boric acid could be pumped through the boric acid monitor cell (Figure 6). Stability, temperature, and calibration measurements were made with this system. 


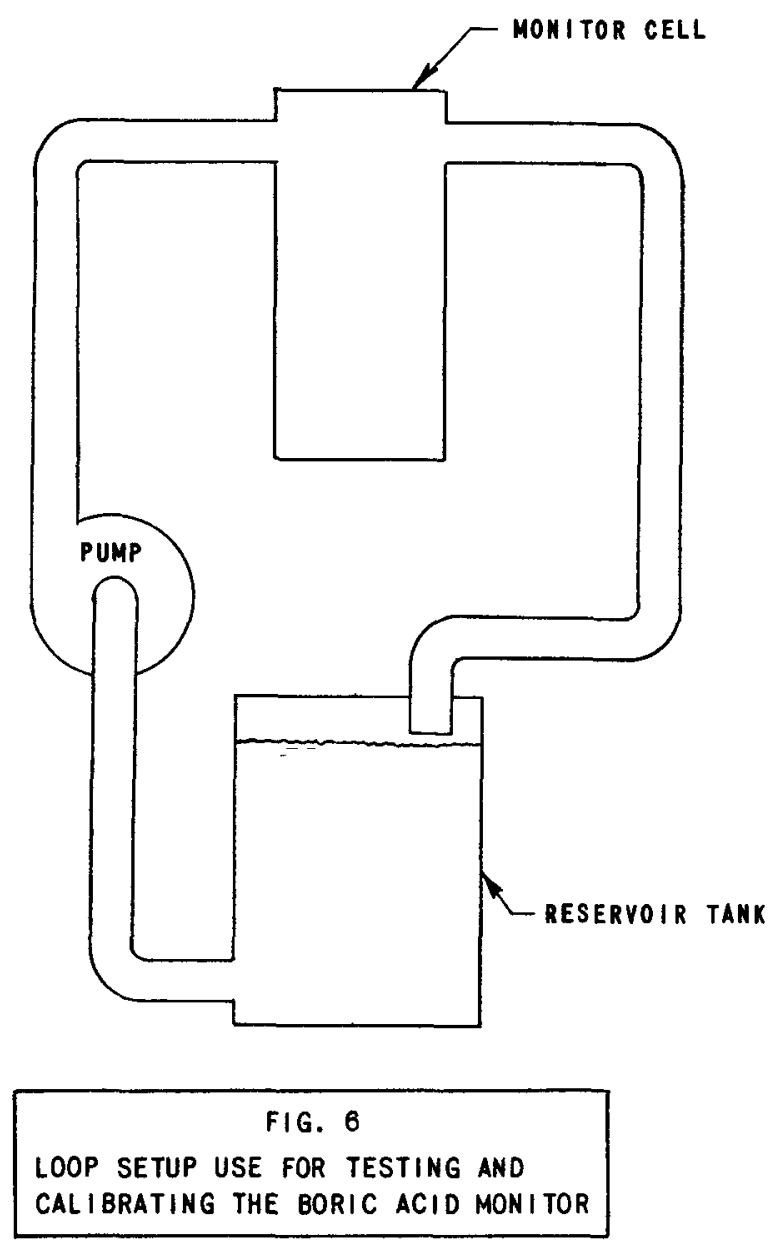

The stability of the system depends upon the stability of the ionization chamber power supply, the VRE, and the feedback voltage supply. Experience with the electrometer has shown it to be very stable. The ionization chamber is being operated well on its plateau, so that small voltage variations cause no problem. The feedback voltage must be very stable because a $1 \%$ change in the feedback voltage can cause a net change of as much as $10 \mathrm{mv}$ or an error of $\$ 0.26 \mathrm{gm}$ per liter. A transistorized voltage supply modified to have a variable output of 0 to 1 volt is used for this circuit. Previous measurements indicated that the output should vary not more than $\pm 0.1 \mathrm{mv}$ in 1 volt.

The stability check of the entire system was made in the following manner: The circuitry was assembled, and demineralized water was pumped through the system. A zero reading on the recorder was obtained with the feedback power supply, and it was left in this condition for three days. At the end of this time, the recorder trace was inspected, and the maximum drift that was observed was less than $1 \mathrm{mv}$. This test was repeated several times with the same result, indicating that the system is quite stable. 
To determine the instrument response to temperature variation, an immersion heater was placed in the reservoir of the loop. The temperature was varied from $25^{\circ} \mathrm{C}$ to $55^{\circ} \mathrm{C}$, corresponding to the expected temperature variation of the moderator where the cell was installed. Instrument response versus moderator temperature was plotted for demineralized water, and for boric acid concentrations of $1.02 \mathrm{gm} /$ iter, $1.43 \mathrm{gm} / 1$ iter, and $2.51 \mathrm{gm} /$ liter (see Figures 7 to 10 ). In each case the slope of the line was $-0.05 \mathrm{mv} /{ }^{\circ} \mathrm{C} \pm 50 \%$. Even though the relative error in this is large, the absolute error is small. For a temperature change of $40^{\circ} \mathrm{C}$, the change in instrument response is only $2 \mathrm{mv} \pm 1 \mathrm{mv}$.

The error requirement for the instrument is $\pm 0.05 \mathrm{gm} /$ liter, which corresponds roughly to $<2 \mathrm{mv}$. Since the change in response with temperature is less than the accuracy requirement, there is no need for temperature compensation, although a correction could easily be made if desired. It is noted here that the temperature response below $25^{\circ} \mathrm{C}$ and above $55^{\circ} \mathrm{C}$ has not been investigated and is unknown.

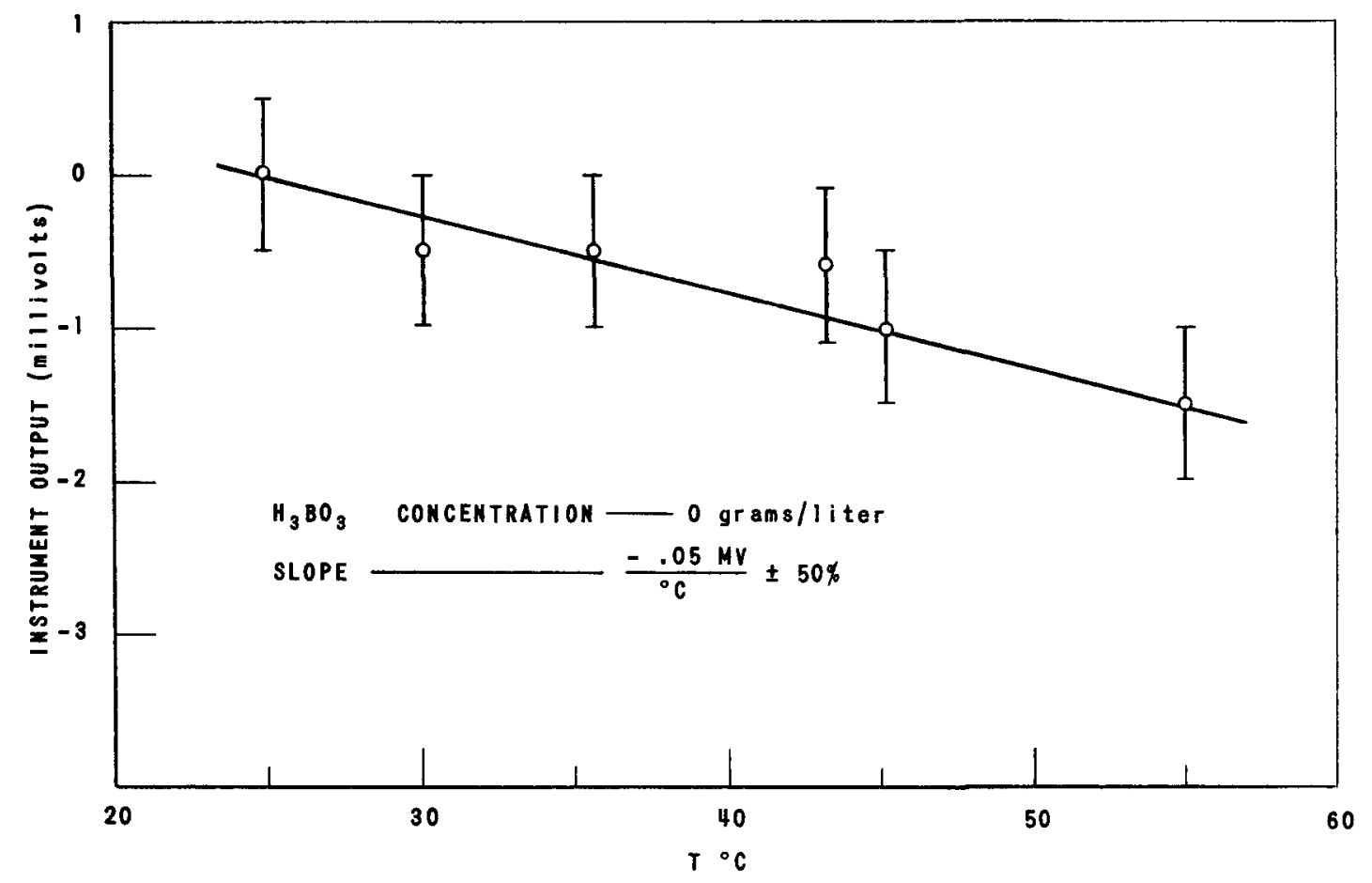

FIG. 7

INSTRUMENT RESPONSE AS A FUNCTION OF TEMPERATURE 


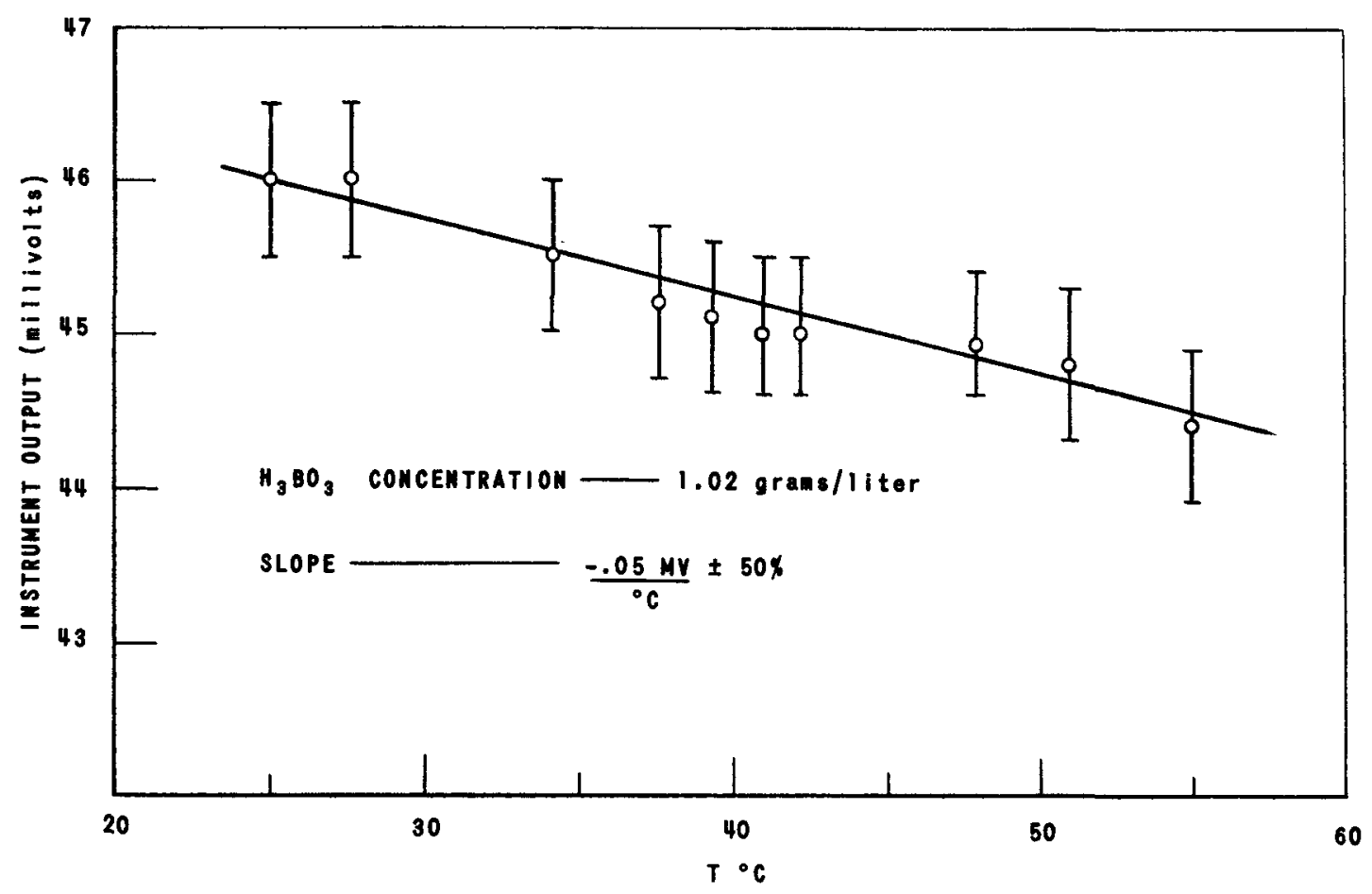

FIG. 8

INSTRUMENT RESPONSE AS A

FUNCTION OF TEMPERATURE

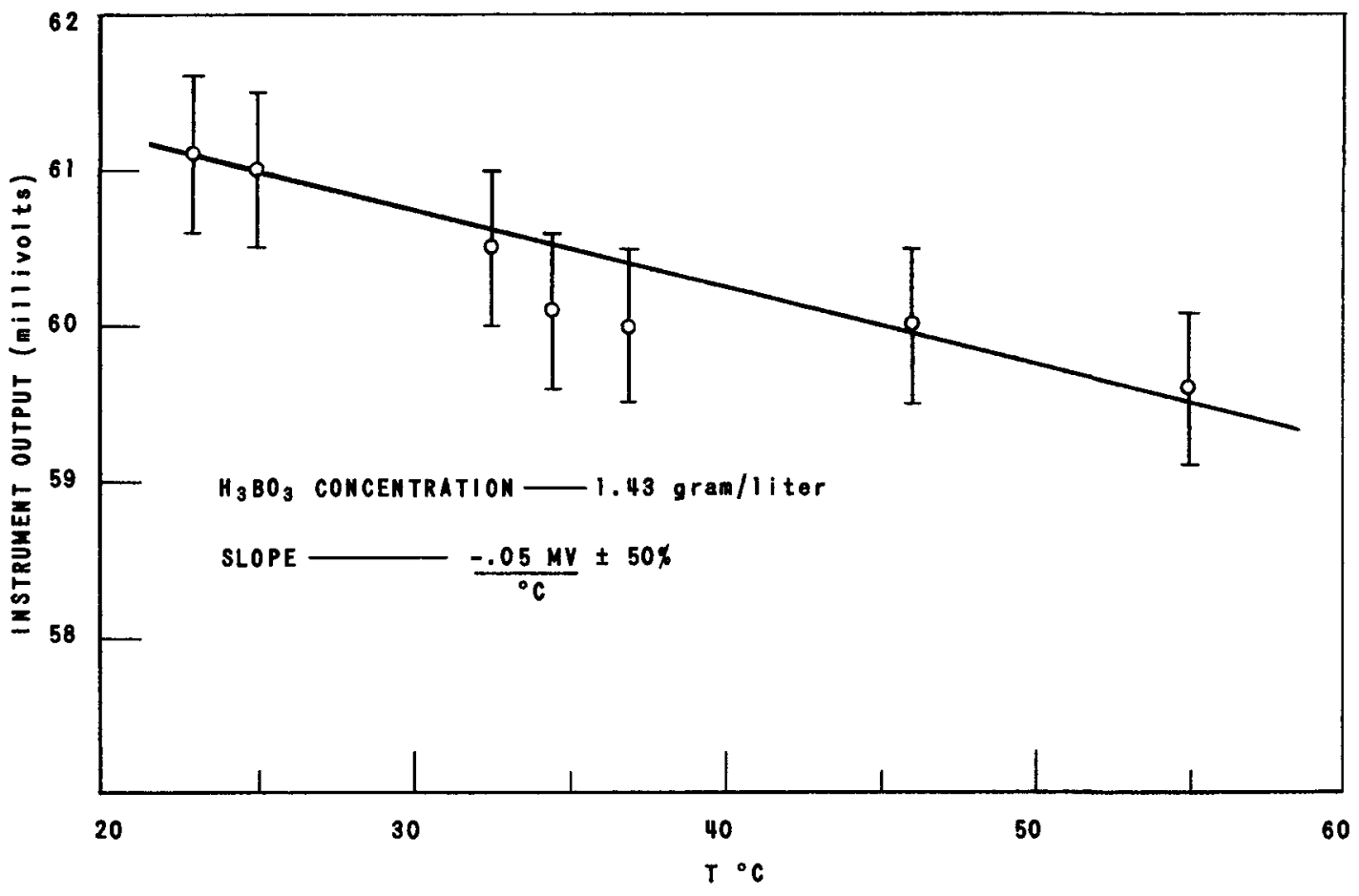

FIG. 9

INSTRUMENT RESPONSE AS A

FUNCTION OF TEMPERATURE 


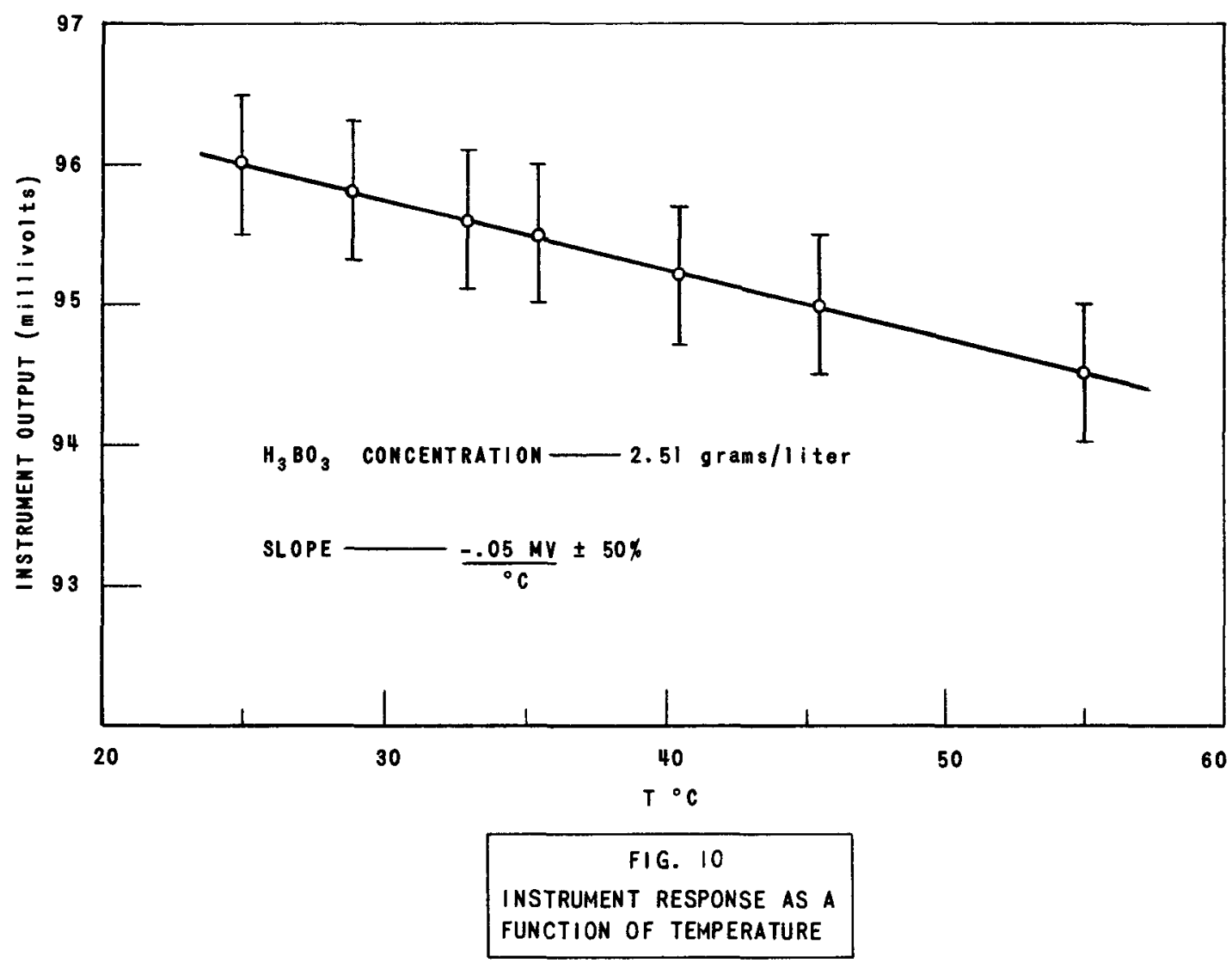

IV. CALIBRATION

The calibration of the system was performed in the loop.

Demineralized water was pumped from the reservoir to the monitor cell and back to the reservoir. The water temperature was kept at $25^{\circ} \mathrm{C}$, and the instrument was zeroed at this temperature. Small amounts of concentrated boric acid solution were added to the reservoir, and the system was allowed to reach equilibrium. Samples were drawn from the loop, and analyses were made for boric acid concentration by titration with sodium hydroxide.

The signal on the recorder was read corresponding to the various concentrations, and a calibration curve was constructed of instrument response versus boric acid concentration at $25^{\circ} \mathrm{C}$ (Figure 11 ). The center of the trace was read and plotted against concentration. If the signal is read from the recorder chart, the concentration may easily be read to within $0.025 \mathrm{gm} /$ liter at $25^{\circ} \mathrm{C}$. It would be very difficult to achieve this accuracy by reading the panel meter in the control room. If one watches the needle variations for a few moments and averages them, perhaps an accuracy of $\pm 0.05 \mathrm{gm} /$ liter may be read. To read with an accuracy of $\pm 0.025 \mathrm{gm} /$ liter, the recorder chart must be read. If the temperature is above $25^{\circ} \mathrm{C}$ and below $55^{\circ} \mathrm{C}$, the concentration may be corrected to $25^{\circ} \mathrm{C}$ by using the temperature coefficient of $-0.05 \mathrm{mv} /{ }^{\circ} \mathrm{C}$ indicated above. 


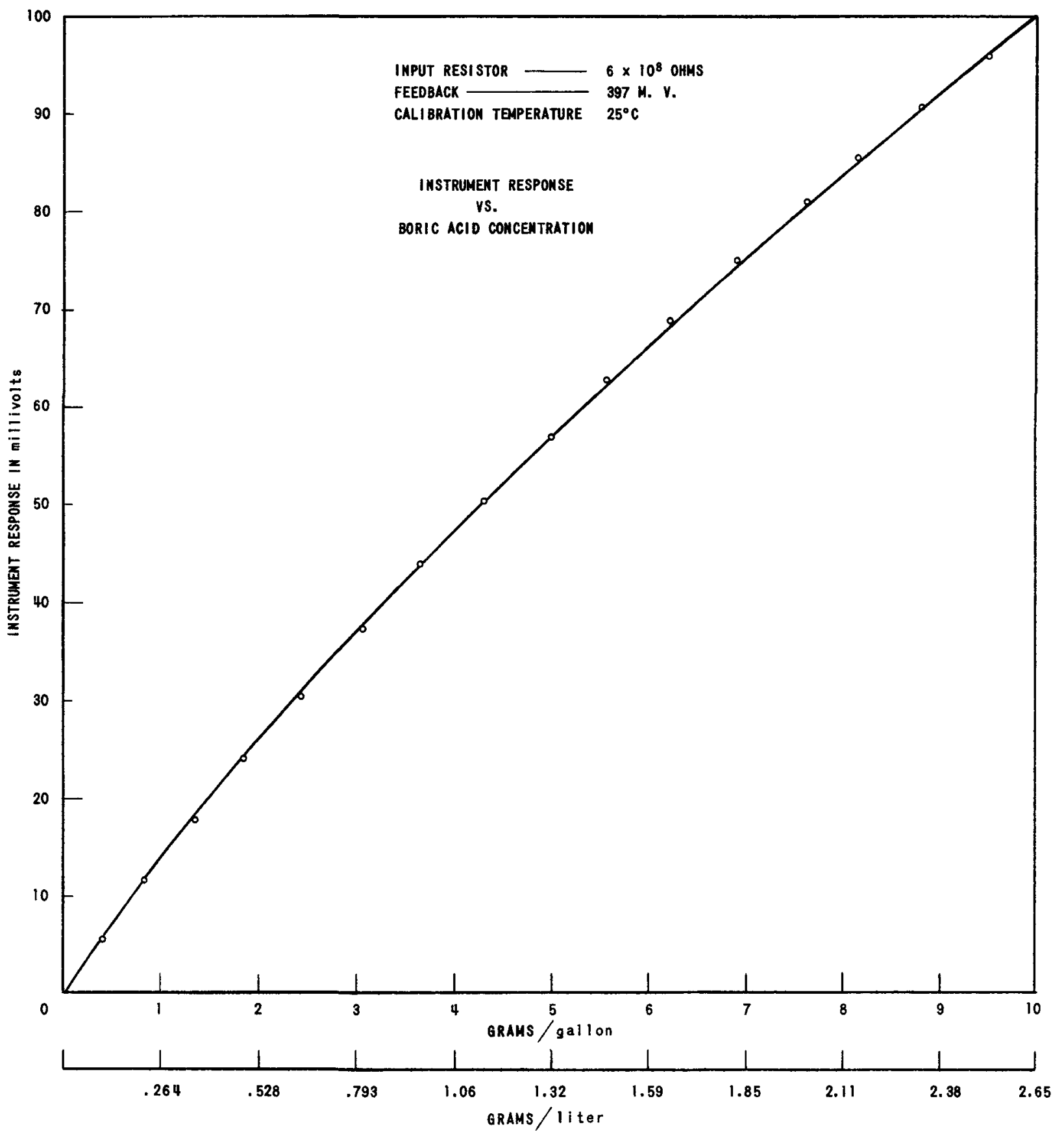

FIG. II

MONITOR CALIBRATION CURVE

The monitor cell and associated electronics were set up in the test loop and calibrated with known concentration of boric acid. The system was checked periodically by additions and removal of boric acid from the loop. The loop concentration was tested chemically and compared with the results obtained from the monitoring system. The agreement between the two was very good, as shown by samples in Table II. 
Table II

COMPARISON OF MONITOR AND CHEMICAL RESULTS

\begin{tabular}{|c|c|c|c|}
\hline Sample & $\begin{array}{c}\text { Monitor Reading } \\
\text { (gm/liter) }\end{array}$ & $\begin{array}{c}\text { Chemical Analysis } \\
\text { Result (gm/liter) }\end{array}$ & Deviation \\
\hline 1 & 0.409 & 0.394 & 0.015 \\
2 & 0.970 & 0.983 & 0.013 \\
3 & 1.64 & 1.64 & 0 \\
4 & 2.52 & 2.51 & 0.01 \\
\hline
\end{tabular}

Once the system has been set up for operation, there should be no need for any further adjustment unless changes take place in the ionization chamber or electronic troubles occur. In those cases a recalibration of the system may be necessary, but if no malfunction occurs, the system should operate indefinitely with no adjustments.

\section{INSTALLATION AND INITIAL EXPERIENCE}

The monitoring system is located physically in the basement of Building D-331. The output circuit of the VRE is shown in Figure 12 .

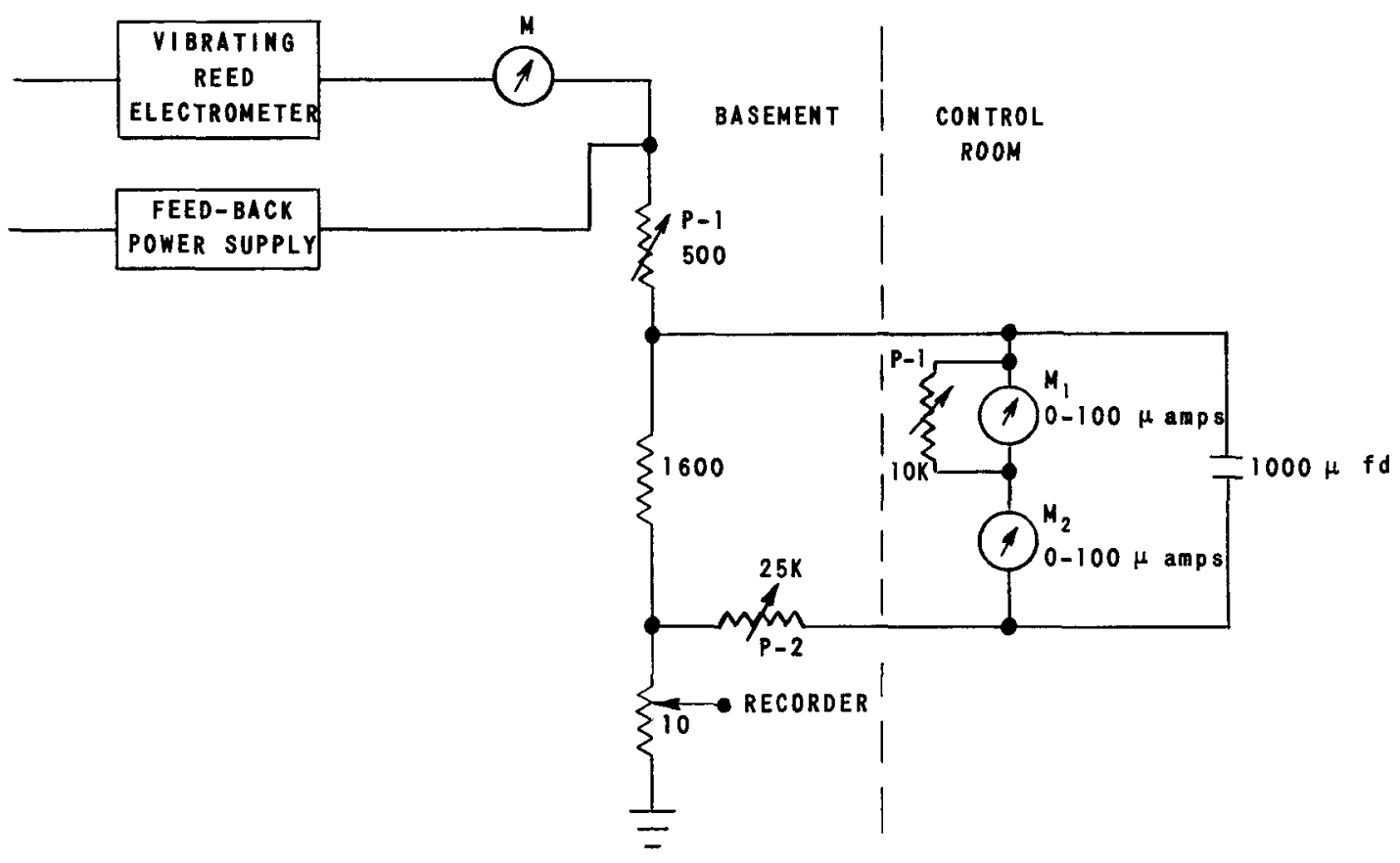

FIG. 12

MODIFIED OUTPUT CIRCUIT OF

VIBRATING REED ELECTROMETER 
Meters $m_{1}$ and $m_{2}$ are 100-microampere movements and are adjusted by means of $\mathrm{p}_{1}, \mathrm{p}_{2}$, and $\mathrm{p}_{3}$ to read the same as the recorder and meter $\mathrm{m}$. A meter relay $m_{1}$ to which the alarm system is connected is located in the control room, and $m_{2}$ is a panel meter (also located in the control room) which displays the concentration signal to the reactor operators. A 100- $\mu \mathrm{f}$ capacitor was connected across meters $m_{1}$ and $m_{2}$ to damp the rather wild needle movements which occur due to the statistical variation in the signal.

A number of situations may arise which will cause the monitor to give erroneous readings. The presence of neutron-absorbing material other than boric acid in the moderator will cause the monitor to read high. Extraneous neutron sources or an unusually high neutron or gamma background will cause the monitor to read low. Air trapped in the monitor cell would give a high reading since moderator is displaced by air. This can be overcome by bleeding the cell periodically. Temperatures below $25^{\circ} \mathrm{C}$ or above $55^{\circ} \mathrm{C}$ may also give trouble, since no calibration measurements were made beyond the se limits.

Since the installation of the boric acid monitoring system in the EBWR, it has been placed in operation during hot and cold critical runs where boric acid was used in the reactor water. Instrument readings were compared with chemical tests on samples drawn from the monitor cell, and the system was seen to be functioning properly. During cold critical runs the moderator temperature in the monitor cell was as low as $12^{\circ} \mathrm{C}$, which resulted in high instrument readings. A temperature correction reduced the reading to within the required instrument error. This is not expected to be a problem during power runs, since the moderator temperature should never go below $25^{\circ} \mathrm{C}$. High readings were observed at other occasions due to air trapped in the monitor cell. Bleeding of the cell remedied this situation. 


\section{APPENDIX}

Neutron Source

Source No.

M-856

Neutron Output

$1.28 \times 10^{7}$ neutrons $/ \mathrm{sec}$

Plutonium Content

$110.02 \mathrm{gm}$

Beryllium Content

$54.01 \mathrm{gm}$

Half-life

24,600 yr

Outer Jacket Material

Type 304 stainless steel

Outer Dimensions

$3.94 \mathrm{~cm} \mathrm{x} 6.57 \mathrm{~cm}$ long

Temperature

May be maintained at $500^{\circ} \mathrm{C}$ indefinitely

Manufacturer

Mound Laboratory

Miamisburg, Ohio

\section{Detector}

Neutron Ion Current Chamber -

Model NL-IC2G

Dimensions

Sensitivity to Neutrons

Sensitivity to Gammas

$4.13 \mathrm{~cm}$ diam $\times 55.6 \mathrm{~cm}$ long

$2.15 \times 10^{-13} \mathrm{amp} / \mathrm{nv}$

Signal to Case Leakage at $315^{\circ} \mathrm{C}$

$1.9 \times 10^{-11} \mathrm{amp} / \mathrm{r} / \mathrm{hr}$

Signal to Case Capacity

$10^{12}$ ohms

Manufacturer

30 micromicrofarads

Neutronics Laboratory

Tinley Park, Illinois

\section{Electrometer}

Vibrating Reed Electrometer -

Mode1 30

Input Impedance

$10^{16} \mathrm{ohms}$

Sensitivity

$10^{-16} \mathrm{amp}$

Manufacturer

Applied Physics Corporation Pasadena, California 
Feedback Power Supply

Transistorized d-c Power Supply Model P98-58462

$\begin{array}{ll}\text { Output } & 0 / 1 \text { volt variable } \\ & 9.0 \text { volts fixed } \\ \text { Manufacturer } & \text { Electronics Division } \\ & \text { Argonne National Laboratory }\end{array}$

$\underline{\text { Recorder }}$

Brown Strip Chart Recorder

Range

$-1 / 0 / 10$ millivolts

Manufacturer

Minneapolis Honeywell

Philadelphia, Pennsylvania

$\underline{\text { Monitor Cell }}$

Fabricator

(see Figure 2)

Central Shops

Argonne National Laboratory 


\section{REFERENCES}

1. E. A. Wimunc and J. M. Harrer, Hazards Evaluation Report Associated with the Operation of EBWR at $100 \mathrm{Mw}$, ANL-5781-Addendum (Rev. 1) (October, 1960).

2. D. D. DeFord and R. S. Braman, Study of Neutron Absorptiometry and Its Application to the Determination of Boron, Analytical Chemistry (November, 1958).

3. R. A. Mattson, The Determination of Soluble Poison Concentration in $\mathrm{H}_{2} \mathrm{O}, \mathrm{TID}-6143(1957)$.

\section{ACKNOW LEDGMENT}

The author wishes to thank E. F. Groh for his assistance in the design of equipment for preliminary experiments, and A. P. Gavin and the Reactor Engineering Drafting Section for assistance in the final design of the monitor cell. Appreciation is also extended to Jack Haugsnes for his advice and consideration. 